\title{
A PÉCSI VILÁGÖRÖKSÉGI TERÜLETEKHEZ KAPCSOLÓDÓ KÖZTEREK REHABILITÁCIÓJA
}

\section{REHABILITATION OF PUBLIC SQUARES CONNECTED TO THE WORLD HERITAGE AREAS OF PÉCS}

\author{
Paczolai Kinga Éva ${ }^{1}$, Kósa Balázs ${ }^{2}$, Németh-Szigeti Renáta ${ }^{3}$ \\ ${ }^{1}$ Pécsi Tudományegyetem, Müszaki és Informatikai Kar, Építészeti és Várostervezési \\ Tanszék 7624, Magyarország, Pécs, Boszorkány út 2.; Tel:+36-72-503-650-23836, \\ paczolaik@gmail.com \\ ${ }^{2}$ Pécsi Tudományegyetem, Müszaki és Informatikai Kar, Vizuális Ismeretek Tanszék \\ 7624, Magyarország, Pécs, Boszorkány út 2.; Telefon / Fax: +36-72-503-650-3836, \\ kosa.balazs@mik.pte.hu \\ ${ }^{3}$ Pécsi Tudományegyetem, Müszaki és Informatikai Kar, Mérnöki Ismeretek Tanszék \\ 7624, Magyarország, Pécs, Boszorkány út 2.; Telefon / Fax: +36-72-503-650-3836, \\ reni.szigeti@gmail.com
}

\begin{abstract}
The World Heritage Square at Pécs is to be constructed in the framework of a program dedicated to develop the locations of the World Heritage. The aim is to rehabilitate the squares belonging to the World Heritage in the hope of increasing the attendance on a conceptual thinking. The study focuses on the marked areas with the purpose of connecting the Castle Wall and its walkway. The rehabilitation even spreads to constructing the area in front of the Old Christian Mausoleum.
\end{abstract}

Keywords: World Heritage, walkway, Barbakán, Pécs, public square.

\section{Összefoglalás}

A Világörökségi helyszínek fejlesztése program keretén belül tervezésre kerül a pécsi „Világörökségi Negyed”. A fejlesztés koncepcionális síkon a látogatottság növelése érdekében a Világörökségi területekhez tartozó közterek rehabilitációját kiemelt szinten kezeli. A tanulmány a programban megjelölt terület egy részét körbe ölelő várfal és a hozzá kapcsolódó várfalsétány folyamatossá tételére és az Ókeresztény Mauzóleum előtti tér rendezésére fókuszál.

Kulcsszavak: Világörökség, várfal sétány, Barbakán, Pécs, köztér.

\section{Várfalsétány koncepciója}

A Világörökségi Negyed helyszíneinek látogatásához kész programkínálatként javasolt egy jól körülhatárolt és összekapcsolt látogatói útvonal, amelyet opcionálisan egy kültéri várfal menti séta is kiegészít az északi várfalsétányon kialakítandó történelmi tanösvény mentén.
A várfalsétány a Dóm Kőtártól északkeletre húzódó kertterületről indul. Az itt megbújó terület kiváló lehetőséget rejt magában, feltétlenül szükséges azonban a zöldfelület rehabilitációja és célirányos fejlesztések véghezvitele. A kert közepén elhelyezkedő „sövénylabirintus” rossz állapotban van, az alkotó növényzet megmentésének lehetősége is kérdéses. A konstrukció 
önmagában értékes, ezért a labirintus elvét megtartva új térkonstrukciót hozunk létre. Gumiőrleményböl alkotjuk újra a labirintust lehetőséget adva egy új funkciónak, a gyerekeknek szánt biztonságos és egyedi játéknak. A nyugodt környezet alkalmas rendezvényszervezésre is. Ezt kiszolgálva kialakítunk egy mobil színpadot hozzá tartozó nézőtérrel. A színpadot a kert dél-nyugati sarkára helyezzük, így megfelelő tér marad a közönség számára, a monumentális térélményt és a kiemelkedő hátteret pedig a $\mathrm{Ba}$ zilika égbetörő tömege biztosítja.

A sétány folyamatossága érdekében átkötés szükséges a kert és a már felújított sétány szakasz között, mely a Középkori Egyetemtől északra húzódik. Egy ,gyilokjárót” kapcsolunk az egyes bástya keleti oldalához, mely feljutást biztosít a bástya felső szintjére. A bástya és a gyilokjáró ad helyet az első információs pontnak. A funkcionális lefedés kérdése több fázison esett át, végül fém fedést kapott, kívülről perforált kompozitlemezzel burkoljuk.

Nyugati irányba tovább haladva a kettes bástya a már felújított sétányszakaszhoz tartozik. Ez lesz a következő információs pont a történeti tárlatvezetésben. A meglévő fa lelépcsőzés fölé szintén acélszerkezetből kiemelt járófelületet készítünk, így lehetőséget adva, hogy a bástya egyfajta kilátópontként és müködjön. A hármas bástya is megállító infópontok egyike lesz, itt az információs pont és a térvilágítás fejlesztésén kívül más változtatásra nincs szükség.

Az észak-nyugati várfalsétány jelen állapotában nem kialakított. A fejlesztés keretében a terület takarítása és a zöld környezet rendbetétele elengedhetetlen. A Püspöki vár falának restaurálása folyamatban van, de a korrózió és a növényzet rongáló hatása miatt szükséges lesz a külső várfal komolyabb tisztítása és renoválása is. A járófelület nyomvonalát a már felújított sétányhoz hasonlóan kavicsterítéssel látjuk el a tereprendezés után. Ez lehetővé teszi a négyes bástya kilátópontként való használhatóságát is.

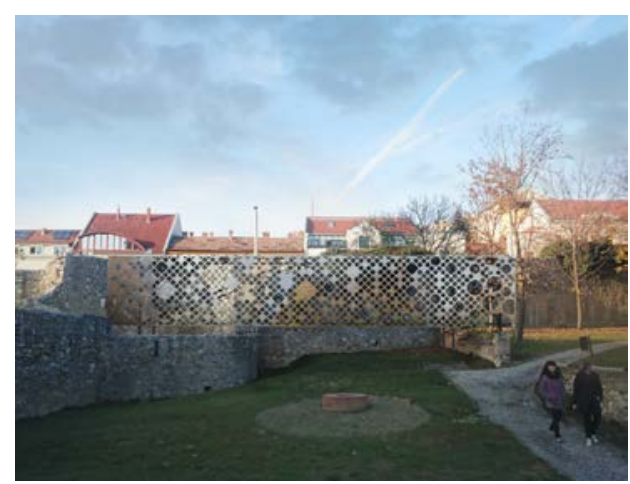

1. ábra. Pécs, I. Bástyához és gyilokjárótervezett koncepció alapján készült látványterv

Az észak-nyugati várfalsétányból a Barbakán-árok felett egy hídon keresztül vezetjük tovább a látogatókat a Barbakán térre. A híd egyszerre fizikai és történelmi kapocs.

A magasfényü perforált alumínium kompozitlemezzel burkolt rozsdamentes acél rácsostartó szerkezet délibábként bújik meg a gesztenyefák között. Vizuális megjelenésében hasonul az egyes bástya kialakításához, a gyilokjáró szimbolikus formáit tükrözi vissza, ezzel keretbe foglalja a fejlesztés célterületeit.

Az árok felett átjutva érkezünk az ötödik bástyához. A Barbakán bástya és szük környezete egy korábbi beruházás során már felújításra került. A Barbakán kert átjárójának átalakítása szükséges egy nagyvonalúbb átkötési megoldással.

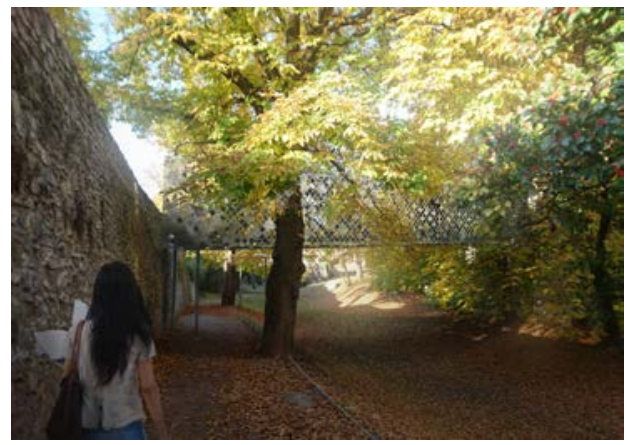

2. ábra. Pécs, Barbakán-árok feletti híd tervezett koncepció alapján készült látványterv 
A kert zöldterületeinek rehabilitációja, megfelelő térvilágításának kialakítása és térburkolatainak cseréje elengedhetetlen.

\section{2. Ókeresztény Mauzóleum}

A világörökségi séta nem lenne teljes az Ókeresztény Mauzóleum említése nélkül (bejárata a Szent István térről közelíthető meg). 1975-ben, az addig itt lépcsőzetesen folyó vízesés javítási munkálatai közben bukkantak a kétszintes épületre, melynek felszíni épülete az emlékezés helye volt, míg a sírkamrában temetkeztek.1 Valószínüleg a IV. század 70-es, 80-as éveiben építhették legalább két építési periódusban, melynek mindegyike érintette a sírkamrát is, miután a második építési periódusra esik annak bővítése, illetve két újabb szarkofág behelyezése. 2

A sétány lejtős terepén haladva könnyen elvétjük a temetőkápolna maradványait és így a térszín alatt rejlő sírkamrát. A figyelem felkeltése kiemelt jelentőségü ezen a ponton. Ahhoz, hogy megragadjuk az emberek tekintetét és lecsaljuk a látogatókat a tér alakítására és egy megfelelő térszíni fogadóépítmény kialakítására van szükség.

$\mathrm{Az}$ Ókeresztény Mauzóleum térszín alatti védőépületéhez való lejutást egy fém zsiliprendszer biztosítja mely a lépcsőre nyit. A zsilip nem ad lehetőséget a folyamatos nyitva tartásra és kizárja a megfelelő múzeumi előtér meglétét. A védőépület gépészeti és elektromos rendszere elavult, nem szolgálja megfelelően az épület müködését. A meglévő bejárat túlzottan rejtett, akna jellegü, melyre a déli oldalon a bokrokkal beültetett rézsủ csak még jobban ráerösít.

A fejlesztés keretében új bejárati építményt készítünk a Mauzóleumhoz. A meglévő lejárati lépcsőt megtartjuk, de a zsilipet elbontjuk. A tervezett állapotban a nyugati támfal helyére, de a nyomvonallal egyező falazattal kiegészítve egy félköríves tömeget helyezünk el, mely megadja a térszínen a lehetőséget a bejárat kiképzésére és a jegypénztár kialakítására. A bejárati épület három tömegi szakaszra bontható. A nyugati oldal fehér félkör alakú tömeg, mely alacsony hajlásszögü, szintén fehér fémlemez fedést kap; a bejárati üvegsáv, mely üvegtető fedést kap; és a keleti oldali homlokzati fal, mely Pixelbetonból kerül kialakításra. A pixelbeton lehetöséget ad arra, hogy a belső-külső tér között fény-árnyék játék és a látogatók mozgásának kompozíciója véletlenszerü és mozgalmas játékot kölcsönöz a felületnek.

A romokat térszín alatt és felett is restaurálni kell. A projekt során az épület gépészeti és elektromos rendszerét felújítjuk, hogy a későbbiekben az épület kompletten megfelelően üzemeltethető legyen, és biztosítható legyen a megfelelö megvilágítás és légállapot a romok számára.

A déli oldali rézsün tereprendezést hajtunk végre. A meglévő meredek rézsüt laposítjuk, ezáltal jobban kinyitjuk a mauzóleum térszíni romjait és a bejáratot a Szent István tér felé. Megszünik az akna jelleg, könnyebben megtalálható és megközelíthető lesz a tér. A tér burkolása pedig lehetöséget biztosít különböző rendezvények megtartására. A kelet-nyugati irányú átjárhatóság a tervezett állapotban sem sérül.

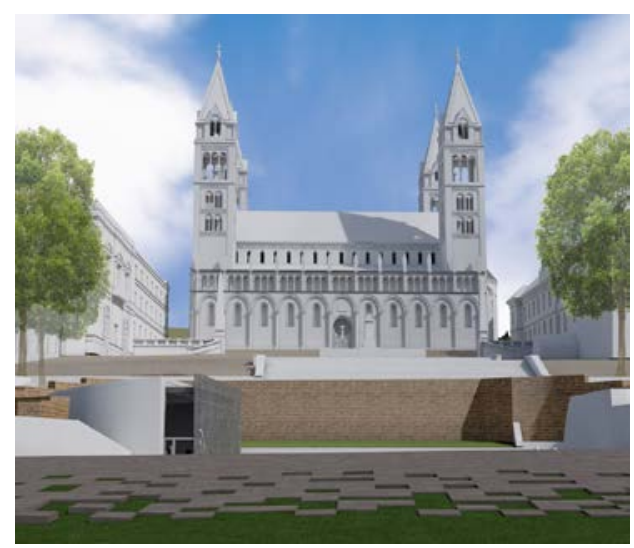

3. ábra. Pécs, Ókeresztény Mauzóleum tervezett koncepció alapján készült látványterv 


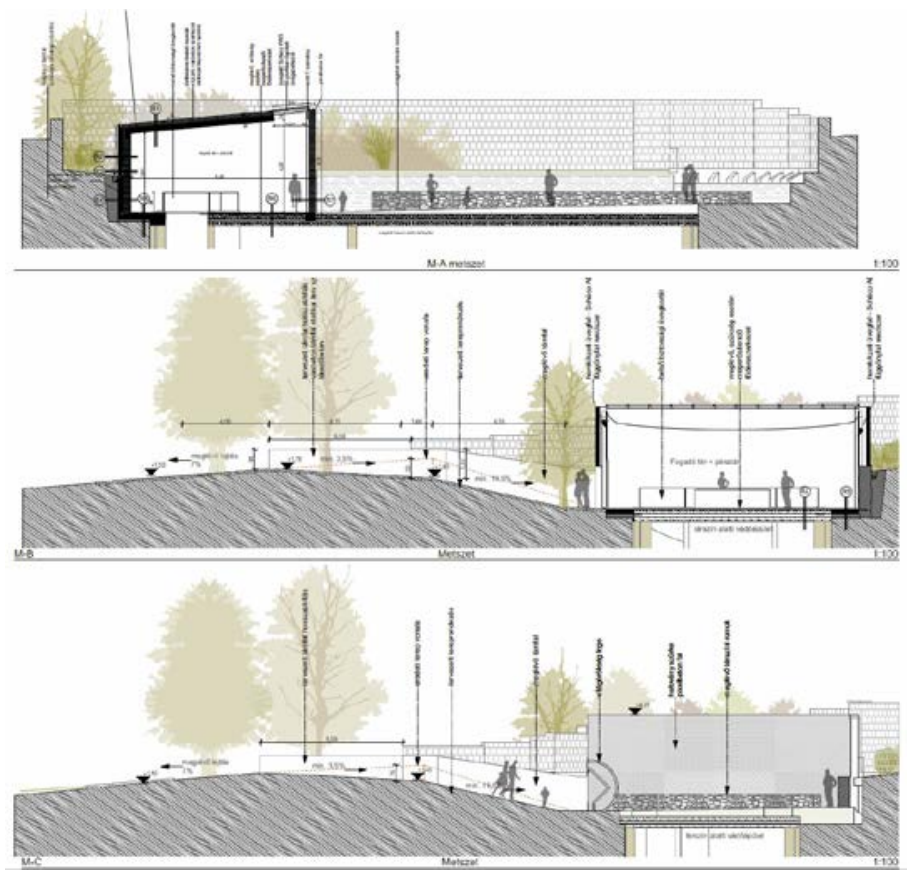

4. ábra. Pécs, Ókeresztény Mauzóleum tervezett koncepció alapján készült látványterv

\section{Következtetések}

A Dóm tér-Szent István tér-Apáca utcaSzéchenyi tér-Káptalan utca által lehatárolt terület kiemelt fontosságú része a város turisztikai fejlődésének régészetimüvészettörténeti értékei miatt. A jelenlegi szituációban szakaszosan helyezkednek el a látványosságok, programszerü látogatásuk körülményes. A cél az ókori emlékek és más korokból származó különféle épített örökség bemutathatóságának megtervezése a mai igényeknek megfelelő kortárs eszközökkel. Ez a fajta törekvés már egy-egy helyszínen elindult és ezt szeretnénk méltóképpen folytatni olyan kiegészítö eszközökkel és bemutatási módokkal, amelyeket összehangolva a müemlékvédelmi előírásokkal, felfüzve egy jól körülhatárolt látogatói útvonalra, igazán izgalmas turisztikai attrakciót ígérhet az érdeklődőknek.
Közfunkció révén fontos kielégíteni a helyi igényeket és a szórakozási lehetőségeket is, így a látogathatóság és körüljárhatóság mellett a huzamosabb tartózkodásra alkalmas téralkotás is részét képezi a fejlesztésnek. Az új rendezvényterek helyet adnának különböző programoknak, koncerteknek, mely hozzájárulna a város szociális fejlődéséhez, ezáltal érzékelhetővé válna a város Világörökségi helyszíneinek tényleges „Világörökségi Negyed”-ként való használata.

\section{Szakirodalmi hivatkozások}

[1] Bozóky Anita: Világörökségi helyszínek Pécs. Múltunk tükre, jövőnk gyökere. Kiadja a Zsolnay Örökségkezelő Nonprofit Kft., Pécs, 2013,1-23. ISBN: 978-963-89844-3-2

[2] Pozsárkó Csaba; Tóth Zsolt: Pécs a római korban Vezetö a pécsi világörökség helyszíneihez. Kiadja a Zsolnay Örökségkeze1ő Nonprofit Kft., Pécs, 2011, 6-9. ISBN: 978-963-89319-0-0 